\title{
Gender, Collecting Practices, Museums
}

\author{
Maria Margaret Lopes \\ Núcleo de Estudos de Gênero-PAGU/UNICAMP \\ PPG Ciência da Informação/UnB, Brazil \\ IHC-CEHFCi/UÉvora, Portugal*
}

Since the late 1980s, "Boundary objects" has become a reference article for the study of objects, museums and collections, in the context of social studies of science. It was not widely followed in what constituted, however, an exemplary study of how to subtly articulate the issues that this dossier addresses. Susan Star and James Griesemer articulated gender dimensions in the proposal, funding and coordination of the activities of the Vertebrate Zoology Museum of The University of Berkeley, California, which also discussed the difficulties in mapping the unclear boundaries between amateurs and professionals in the collecting practice ${ }^{1}$ If these boundaries were more noticeable in the collecting practices of women, it was one of the first questions raised by Ana Carneiro, the chief editor of HoST, when she proposed the still innovative challenge of questioning gender and collections relationships in the history of science and museums.

The articles of this dossier referred to museums located in Mozambique, Brazil and Argentina. Far from trying to map the disciplinary fields or general historiographical productions of countries, the articles assembled here are based on the now familiar perspective to historians of science that "geography has been central to the shaping of scientific cultures"' 2 for their local

\footnotetext{
*Maria Margaret Lopes is grateful to HoST for the opportunity to coordinate this issue, and to $\mathrm{CNPq}$ /Brazil, for supporting her research.

${ }^{1}$ Susan Leigh Star and James R. Griesemer, "Institutional Ecology, 'Translations' and Boundary Objects: Amateurs and professionals in Berkeley's Museum of Vertebrate Zoology, 1907-39," Social Studies of Science, 19-3 (1989): 387-420

${ }^{2}$ Simon Naylor, "Introduction: historical geographies of science-place, contexts, car-
} 
production contexts as well as for the networks through which knowledge and objects circulate. In fact, the networks created by the women discussed in this dossier represent one of the common points laid out in all the articles. These articles are a small sample of what has been done, what can be done and how much still has to be investigated in the gender intersection markers in the history of science, history of collections and of museums in different spaces and times.

Since the 1980s, studies of "Gender and Science" 3 have been institutionalized. Foundational studies such as those of Evelyn Fox Keller, Sandra Harding, Helen Longino, Anne Fausto-Sterling, Donna Haraway, Londa Schiebinger, Ludmilla Jordanova and other authors, presented critical reviews on the historiography of the construction of science, technology and medicine 4 These and other authors such as Susan Star, Emily Martin, Nelly Oudshoorn, Eulália Perez Sedeño, Lorraine Daston questioned the Mertonian norms of objectivity, the neutrality of scientific practices, to highlight the invisibility of women in the history of science, technology and medicine in order to discuss how gender hierarchies have directed research, shaping priorities and scientific theories and marked the historicity of concepts 5

These discussions accompanied the general discourse in gender studies, women and feminism in the various subject areas $\sqrt{6}$ Some authors considered

tographies," The British Journal for the History of Science, 38 (2005): 1-12, on p. 4.

${ }^{3}$ The article of Evelyn Fox Keller "Gender and Science," Psychoanalysis and Contemporary Thought 1 (1978): 409-433, when the terms were associated for the first time, is unanimously noted in the literature as being foundational to the study area. In this paper the author questioned the myth status, which could not be investigated, about the association between masculinity and scientific thinking, as it came into conflict with the dominant image of science gender and neutral emotions. Evelyn Fox Keller, "The Origin, History, and Politics of the Subject Called 'Gender and Science'," in Handbook of Science and Technology Studies, ed. Sheila Jasanoff, Gerald E. Markle, James C. Petersen and Trevor Pinch (Thousand Oaks: Sage Publishing, 1995), 80-94.

${ }^{4}$ See for instance: Angela N.H.Creager, Elizabeth Lunbeck and Londa Schiebinger, eds., Feminism in twentieth-century. Science, Technology, and Medicine (Chicago: The University of Chicago Press, 2001). Teresa Levy and Clara Queiroz, Ciência e Género. Quatro Textos de Quatro Mulheres (Lisboa: CFCUL-Faculdade de Ciências da Universidade de Lisboa, 2005). Maria Margaret Lopes, "Sobre convenções em torno de argumentos de autoridade," Cadernos Pagu, (2006): 35-61. http://www.scielo.br/pdf/cpa/n27/32138. pdf. [accessed October, 13, 2015].

${ }^{3}$ Maria Margaret Lopes, Rebeca Buzzo Feltrin, Bruna Mendes de Vasconcellos sand Maria Cleófas Faggion Alencar, "Intersecções e interações: Gênero em Ciências e Tecnologias na América Latina," in Perspectivas latinoamericanas en el estudio social de la ciencia, la tecnología y el conocimiento, ed. Pablo Kreimer, Hebe Vessuri, Léa Velho and Antonio Arellano (Ciudad de Mexico: Siglo XXI, 2014), 233-243.

${ }^{6}$ To date, influential publications like Signs: Journal of Women in Culture and Society, 
that studies on women in science were perspectives used to mask how gender norms historically, socially, politically and cognitively encompass science and technology systems. But since the late nineties, these interpretations were nuanced and OSIRIS, recognizing the contribution of women and gender studies to analyze the history of science, dedicated a volume to the research field $]^{7}$ It was no longer about simply incorporating more women in traditional stories, but rather to question the making of the history of science and technology $\left.\right|^{8}$ Broad research themes and analytical perspectives were opened and these increasingly considered how gender relations - which indicated the presence or absence of women in various areas of knowledge ranging from Ethnography to Physics, Anthropology to Mathematics-until today structure the access to practices, to careers, and hierarchize the science and technology systems worldwide. 9

The 1980s also marked the growing interest that studies of museums and collections had started to awaken among historians of science. ISIS in 2005 dedicated some of its "focus" to "Museums and the History of Science," finally recognizing that historical studies of museums and collections had established their own discipline. The seminar and the book The Origins of Museums and its ensuing publication, the Journal of the History of Collections were designated as foundational milestones of this process 10 Along these different disciplinary paths in multiple meetings, for some years now, some papers are still bringing inspiring insights on women including how feminist theories or gender studies intersect with museum studies on the history of science, can contribute to increase reflections on these fields. This is the case for example of the analysis by Londa Schiebinger and Donna Haraway about the exhibits of the American Museum of Natural History in New York. These foundational papers questioned to what degree our perceptions about the exhibition practices of science museums are naturalized as the ex-

founded in 1975, holds on to distinguishing the study fields and is identified as an "academic journal of women's and gender studies" http://signsjournal.org/about-signs/ history/ See: Londa Schiebinger, "Introduction: Feminism Inside the Sciences," Signs, 28 (2003): 859-866.

${ }^{7}$ Sally Gregory Kohlstedt and Helen Longino, "The Women, Gender and Science Question. What Do Research on Women in Science and Research on Gender and Science Have to Do with Each Other?," Osiris 12 (1997): 3-15.

${ }^{8}$ Ludmilla Jordanova, "Gender and the Historiography of Science," The British Journal for the History of Science 26 (1993): 469-483.

${ }^{9}$ Among other predominantly North American publications, see Londa Schiebinger's papers, also in "Mais mulheres na ciência: questões de conhecimento", História, Ciências, Saúde, Manguinhos 15 (2008): 269-282.

${ }^{10} \mathrm{Jim}$ Bennett, "Museums and the History of Science. Practitioner's Postscript," Isis 96 (2005): 602-609 
hibits consolidate traditional gender roles. These texts also called attention to how different exhibits incorporate, subtly or explicitly, the engendering of nature and the acritical and a-temporal reproduction of relations between human ancestors and representations of femininity and masculinity ${ }^{11}$ These texts remain as almost obligatory references in the articles that discuss the power of exhibitions to reproduce the gender stereotypes and exclusion of women from scientific practices 12 And these texts also continue, to be quoted in articles of this dossier.

For some time the watchful eye on gender relations has influenced authors who have come to recognize the presence of women in the various collecting practices, distant in time and space. The few, but present, noble or scholarly women who signed the visitors' book of the Ulisse Aldrovandi Museum in Bologna, around 1570, were highlighted in the texts of Paula Findlen ${ }^{13}$ The few mentions of the slave Antonia in the collection, organization and preparation of the "simple" collections of Garcia D'Orta in Goa in 1563, received a note in the English translation of the work, and have become references ${ }^{14}$ Famous collectors such as Maria Sybila Merian ${ }^{15}$ and Mary Anning ${ }^{16}$, for example, have deserved more attention in the literature of the history of science. Less known outside their local contexts, but which began to be incorporated in the historiography of the museums of Span-

\footnotetext{
${ }^{11}$ Analysis of the acritical incorporation of masculinity stereotypes in exhibits of the Museum of Natural History in New York have been conducted, for example, by feminist scholars such as Donna Haraway, Primate Visions: Gender, Race, and Nature in the World of Modern Science, (New York: Routledge, 1989). Anne Fausto-Sterling, "Gender, race and nation: the comparative anatomy of "Hottentot" women in Europe, 1815-1817," in Deviant Bodies. Critical Perspectives on Difference in Science and Popular Culture, ed. Jennifer Terry and Jacqueline Urla (Bloomington: Indiana University Press, 1995), 19-48 and Londa Schiebinger Has Feminism Changed Science? (Cambridge Mass.: Harvard University Press, 2001).

${ }^{12}$ Rebecca Machin, "Gender representation in the Natural History Galleries at the Manchester Museum," in Gender, Sexuality and Museums, ed. Amy K. Levin (New York: Routledge, 2010), 187-200.

${ }^{13}$ Paula Findlen, "Masculine Prerogatives: Gender, Space, and Knowledge in the Early Modern Museum" in Peter Galison and Emily Ann Thompson, The Architecture of Science (Cambridge, MIT Press, 1999), 29-58.

${ }^{14}$ Richard Grove, Green Imperialism: Colonial Expansion, Tropical Island Edens, and Origins of Environmentalism, 1600-1860 (Cambridge: Cambridge University Press, 1995).

${ }^{15}$ See for example Londa Schiebinger, The Mind has No Sex? Women in the Origins of Modern Science (Cambridge: Harvard University Press, 1991); Dániel Margócsy, Commercial Visions. Science, Trade, and Visual Culture in the Dutch Golden Age, (Chicago: Chicago University Press, 2014).

${ }^{16}$ Shelley Emling, The Fossil Hunter: Dinosaurs, Evolution, and the Woman Whose Discoveries Changed the World (New York: Palgrave Macmillan, 2009).
} 
ish colonial countries, are the erudite private collectors who also organized and kept their Natural History cabinets, as for instance Manuela Sanz Santamaria de González Manrique in Santa Fé de Bogotá in 1789 ${ }^{17}$ and Ana María Centeno in Cuzco, between 1832 and 1874 18 It should be kept in mind for example, that many works have been dedicated to the not-so-few British women who worked as wives, assistants, collectors, painters and field botanist, zoologist and geologist at the service of building their respective disciplines and Natural History museums in the 19th century ${ }^{19}$, And also women of "uneasy careers" 20 in the sciences of the twentieth century until today.

Despite all the literature we could continue to mention ${ }^{21}$, we accept for this volume of JHoST the challenge posed by Adrian Desmond, some years ago, for the case of the "emergence of women biologists." We strive to make women collectors visible, whether biologists or not, and museum employees and some gender markers in their practices. We recognize that the study of gender relations in the history of science and of museums is still "a topic crying out for study.' 22

More recent studies of Gender, Sexuality and Museums23, or Museums and Biographies ${ }^{24}$ have cautioned that studies that consider the presence and role of women in museums, especially in art museums, have focused on those

\footnotetext{
${ }^{17}$ María Paola Rodríguez Prada, Le Musée National de Colombie 1823-1830. Histoire d'une création (Paris: L'Harmattan, 2013).

${ }^{18}$ Stefanie Gänger, "The Many Natures of Antiquities: Ana María Centeno and Her Cabinet of Curiosities, Peru, ca. 1832-1874," in Nature and Antiquities. The Making of Archaeology in the Americas, ed. Philip L. Kohl, Irina Podgorny and Stefanie Gänger, (Tucson: The University of Arizona Press, 2014), 110-124.

${ }^{19}$ See as example: Martina Kölbl-Ebert, "British Geology in the Early Nineteenth Century: A Conglomerate with Female Matrix," Earth Sciences History 21 (2002): 3-25.

${ }^{20}$ Pnina Abir-Am and Dorinda Outram, ed., Uneasy careers and Intimate Lives: Women in Science, 1789-1979 (Lives of Women in Science), (New Brunswick: Rutgers University Press, 1987).

${ }^{21}$ See for example María Bolaños Atienza, "Las Mujeres en los Museos: entre museólogas y coleccionistas", in Patrimonio en Femenino (Madrid: Ministerio de la Cultura, 2011), 36-41. http://www.ibermuseus.org/wp-content/uploads/2015/09/Patrimonio.pdf . [accessed October, 13, 2015]; Irene Vaquinhas, "Museus do feminino, museologia de género e o contributo da história," Midas [Online] 3 (2014), http://midas.revues.org/603 [accessed October, 13, 2015].

${ }^{22}$ Adrian Desmond, "Redefining the Axis: "Professionals," "Amateurs" and the Making of Mid-Victorian Biology - A Progress Report," Journal of the History of Biology 34 (2001) 3-50, on p. 19.

${ }^{23}$ Amy K. Levin, ed., Gender Sexuality and Museums (New York: Routledge, 2010).

${ }^{24}$ Kate Hill, ed., Museums and Biographies. Stories, Objects, Identities (Woodbridge: Boydell Press, 2012).
} 
outstanding women who have attained senior positions as exhibition curators and/or directors, and have given less attention to those "quiet forces," 25 women with no, or increasingly with academic training who occupied posts as collectors, donors, research scientists, the assistants, preparators, illustrators, male co-authors and so on, also in the Natural History museum until well into the twentieth century.

The articles in this dossier focus on several of these women. They address the trajectories of women born in the former state of Prussia, in Portugal, Argentina, in the current Czech Republic, and who lived and worked in South America or Africa in the first half of the twentieth century. The authors also believe it is significant to highlight the importance of successful women in their careers and their contributions to scientific practices in museums. Women who in their time were not necessarily under the invisibility which history has attributed to them. Which is not turning them into heroes, but rather insert them within their contexts. That is the meaning of the articles gathered in this dossier on Emilie Snethlage, in the Goeldi Museum in Belém do Pará in Brazil; about Maria Corinta Ferreira in the Dr. Álvaro de Castro Museum, Lourenço Marques, Mozambique; about Wanda Hanke in her relationship with the Paranaense Museum of Curitiba, Brazil; and about Emma Nozzi in the Carmen de Patagones Museum, Argentina. The articles grant prominence to these women. But from all these articles we see other women emerge, which increasingly show that these women were not necessarily exceptions, women "ahead of their time." They may have been fewer in numbers, but they were not the only ones ${ }^{26}$

Inserted in their specific contexts and therefore completely different, the articles of this dossier tell us that Emilie Snethlage and Emma Nozzi took charge of museums they worked at. Emilie Snethlage was the first woman to head a South American museum, the Goeldi Museum 27 Emma Nozzi had a leading role in organizing regional museums in Argentina. Maria Corinta Ferreira was the vice director of the Mozambican Institution. Wanda Hanke, with an academic background in medicine, never achieved an institutional position in museums.

\footnotetext{
${ }^{25}$ Patrick N. Wyse Jackson and Mary Spencer Jones, "The quiet workforce: the various roles of women in geological and natural history museums during the early to mid-1900s," in The Role of Women in the History of Geology, ed. C. V. Burek and B. Higgs (London: Geological Society, London, 2007), Special Publications, 281: 97-113.

${ }^{26}$ Maria Margaret Lopes, "Proeminência na mídia, reputação em ciências: a construção de uma feminista paradigmática e cientista normal no Museu Nacional do Rio de Janeiro," História, Ciências, Saúde-Manguinhos 15 (2008): 73-95.

${ }^{27}$ Maria Margaret Lopes "'Aventureiras' nas ciências: refletindo sobre gênero e história das ciências no Brasil," Cadernos Pagu 10 (1998): 345-368.
} 
The gender perspective in the article by Mariana Sombrio, following the trajectory of ethnographic collections, scientific production and scarcities in the field work of Wanda Hanke, enables us to view the little-explored aspects concerning the networks of rivalries between Brazilian regional museums and the National Museum of Rio de Janeiro over the control of ethnographic findings to be musealised and also their trade.

The attention of María Alejandra Pupio to the "quiet forces", as for instance the teachers of small cities of Argentina, brought forth one of the themes that the recent literature has vastly indicated to be explored, which is not only about gender relations and museums but also concerns the role of men and women as donors of objects for museums.

The international career of Maria Corinta Ferreira, which is explored in the text of Luís Pequito Antunes, cannot be dissociated from the scientific networks and institutional organizations built between the African museums - as of Mozambique and the Transvaal - another theme that has barely been discussed in the international literature of the history of science or museums. This article on Maria Corinta Ferreira facilitates our understanding about some aspects of the complexity of Portuguese colonial policy, which offered little support for the scientific activities in the colony. On the other hand, it was precisely the colonies or their themes that provided greater possibilities to women, who were already professionals in various fields of natural sciences 28 , and held posts and developed their careers either at the Museum of Lisbon or the Museum of Mozambique.

Miriam Junghans points to the gender marks of the scientific trajectory of Emilie Snethlage, of the museum specialized in Amazon Zoology at the National Museum of Rio de Janeiro in Brazil, beginning with her formative years in Europe. Highlighting the scientific and social networks that Emilie Snethlage constructed, the text emphasizes other aspects that increasingly attract the attention of historians of science. Such networks mark the collective nature of scientific enterprises, the practices of which are distributed geographically in different places, involving different actors: teachers in Germany, avifauna specialists, field assistants in Amazonia, employees at all

\footnotetext{
${ }^{28}$ Ana Simões, Ana Carneiro, Maria Paula Diogo, Luís Miguel Carolino, Teresa Salomé Mota,Uma História da Faculdade de Ciências da Universidade de Lisboa (19111974), (Lisboa, Faculdade de Ciências da Universidade de Lisboa, 2013). Maria Margaret Lopes, Madalena Esperança Pina, Maria de Fátima Nunes, "Cruzando fronteiras: a construção de uma tradição para o 1. Congresso Nacional de Ciências Naturais, Lisboa, 1941," in A Atividade da Junta de Educação Nacional, ed., Augusto José dos Santos Fitas, João Príncipe, Maria de Fátima Nunes, Martha Cecília Bustamante (Lisboa: Cehfci/Caleidoscópio, 2012), 115-132.
} 
levels of museums, all explicitly named.

Like in the text on Emilie Snethlage, the other articles of this dossier favor fieldwork, collections of archaeological and ethnographic objects or animal species, scientific articles, the network relationships between people and institutions; in other words, the practices that characterize the knowledge produced in museums. In their research, these women travelled across extensive areas of the Amazon, several countries and large areas of southern America, and Africa. Their initiatives contribute once again to dispel some myths that are still associated with the scientific activities of women in fieldwork, as Alda Heizer and Aline Cerqueira have pointed out: that women were limited to collaborative work with their male colleagues and limited their field work to confined spaces, ${ }^{29}$

Focusing on gender, through these women's performance, the articles of this dossier also open the way to advance in the studies about the scientific disputes and cooperation that occurred between museums, and about the museum organizations that had begun to intensify in Africa or in Argentina.

The articles in this dossier have no intention to answer with an explicit yes or no our editor's question about the boundaries between amateurs and professionals being more impressive in the practices of women collectors. Adrian Desmond recalls that the "amateur" category only had meaning in the mid-nineteenth century in England, precisely to justify the asymmetrical counterpart of those who self-titled themselves as professionals. As Kate Hill states, mentioning Simon Naylor "if naturalists could be characterized by their class or gender, or to a lesser extent by whether they were amateurs or professionals, their engagement with the materiality of natural history was a means by which they could transcend, or modify those social categories. It was itself an agent in the fluidity of the natural history community" 30 and in our case well into the twentieth century. The trajectories of Maria Corinta Ferreira, Emilie Snethlage, Wanda Hanke, Emma Nozzi, the other

\footnotetext{
${ }^{29}$ Alda Heizer and Aline Cardoso Cerqueira, "Joséphine Schouteden-Wéry no litoral belga: uma bióloga entre o trabalho de campo e a formação de coleções," História, Ciência, Saúde - Manguinhos 21 (2014): 1049-1058.

${ }^{30}$ Simon Naylor, "The field, the museum and the lecture hall: The spaces of natural history in Victorian Cornwall" Transactions of the Institute of British Geographers 27 (2002): 494-513. Kate Hill, "He knows me...but not at the museum': women, natural history collecting and museums, 1880-1914," in Narrating objects, collecting stories: essays in honour of Professor Susan M. Pearce, ed. Sandra H. Dudley, Amy Jane Barnes, Jennifer Binnie, Julia Petrov and Jennifer Walklate, (Abingdon: Routledge, 2012), 184-195 on p.186. See also Samuel J.M.M. Alberti, "Amateurs and Professionals in One County: Biology and Natural History in Late Victorian Yorkshire," Journal of the History of Biology 34 (2001): 115-147.
} 
museum scientists and the teachers of the articles in this dossier are precisely additional contributions to the question of whether it makes sense or to what degree it remains a complex issue, to draw the line between amateur and professional men and women in the collecting practices of science, in the localities and times in which these women worked and participated. 